\title{
How the CEFR Is Impacting French-as-a-Second-Language in Ontario, Canada: Teachers' Self-Reported Instructional Practices and Students' Proficiency Exam Results
}

\author{
Katherine Rehner ${ }^{1, *(\mathbb{D})}$, Anne Popovich ${ }^{2}$ a and Ivan Lasan $^{2}(\mathbb{D}$ \\ 1 Department of Language Studies, University of Toronto Mississauga, 3359 Mississauga Road, Mississauga, \\ ON L5L 1C6, Canada \\ 2 Department of Curriculum, Teaching and Learning, OISE, University of Toronto, 252 Bloor Street West, \\ Toronto, ON M5S 1V6, Canada; anne.popovich@mail.utoronto.ca (A.P.); ivan.lasan@mail.utoronto.ca (I.L.) \\ * Correspondence: katherine.rehner@utoronto.ca
}

check for updates

Citation: Rehner, Katherine, Anne Popovich, and Ivan Lasan. 2021. How the CEFR Is Impacting French-asa-Second-Language in Ontario, Canada: Teachers' Self-Reported Instructional Practices and Students' Proficiency Exam Results. Languages 6: 15. https://doi.org/10.3390/ languages6010015

Received: 26 October 2020 Accepted: 16 January 2021 Published: 21 January 2021

Publisher's Note: MDPI stays neutral with regard to jurisdictional claims in published maps and institutional affiliations.

Copyright: (c) 2021 by the authors. Licensee MDPI, Basel, Switzerland. This article is an open access article distributed under the terms and conditions of the Creative Commons Attribution (CC BY) license (https:/ / creativecommons.org/licenses/by/ $4.0 /)$.

\begin{abstract}
This exploratory article describes (1) the self-reported instructional practices of a group of 103 Kindergarten to Grade 12 French-as-a-second-language (FSL) teachers from school boards across Ontario, Canada before and after intensive and extensive professional learning about the Common European Framework of Reference (CEFR) and (2) the areas of strength and opportunities for improvement in the FSL proficiency of 434 Grade 12 students from school boards across Ontario in their final year of study, as measured through their outcomes on the Diplôme d'études en langue française (the FSL proficiency exam aligned with the CEFR). In looking across the findings from these early-CEFR-adopter teachers and these highly-motivated students at the end of their FSL studies, the article offers a window onto how the CEFR is impacting the local landscape of FSL education in the province.
\end{abstract}

Keywords: instructional practices; proficiency outcomes; French as a second language; CEFR; DELF; action-oriented instruction; task-based language teaching

\section{Introduction}

Over the past four decades, French-as-a-second-language (FSL) education in Ontario, Canada has undergone significant changes, with the grammar-based general program descriptions of the 1980s (Ontario Ministry of Education 1980) being replaced by ever-moreelaborate grade- and program-specific curriculum documents. By the late 1990s/early 2000s, requirements for assessment of student achievement had moved from the evaluation of discrete skills to performance-based achievement (Ontario Ministry of Education 1998, 1999, 2000, 2001). For example, the Grade 11 and 12 document (for students aged 16-18 years) for Core French courses (the most-common mode of FSL program delivery in Ontario in which students learn French as a subject) aimed "to provide students with fundamental communication skills in French and an understanding of the nature of the language and its culture" (Ontario Ministry of Education 2000, p. 2). The purpose of the program at that time was to develop oral communication, reading, and writing skills "using a thematic approach" which would provide a variety of contexts for language learning (Ontario Ministry of Education 2000, p. 4). While the guidelines stressed the consistent use of French in the classroom both by students and the teacher, the focus of the learning was also tied to the mastery of a "range of specific language structures" and vocabulary determined by the themes. In the Core French curriculum document for Grades 9 and 10 (for students aged 14-16 years), constant review and re-use of these structures and vocabulary were seen as "essential and natural in language study" and aimed to provide students with the base from which they could build their language capacity "so that they can apply their knowledge of French in situations that are meaningful to them" (Ontario 
Ministry of Education 1999, p. 4). Expectations of the Core French program under these guidelines also included the reading of French literature and an integrated study of the culture of French-language regions. The documents stressed the link between language and culture and therefore insisted that cultural studies "be integrated into daily instruction rather than presented in an isolated fashion or on an occasional basis" (Ontario Ministry of Education 2000, p. 4). The Core French documents proposed as its outcomes a level of French that allowed students to exchange information in verbal communication and to demonstrate global understanding of written and audio materials (Ontario Ministry of Education 2000). These guidelines also foregrounded the interconnectivity of the language skills, in that through their oral and reading experiences students would "acquire the skills they need to become good writers who are able to communicate ideas and opinions with ease and clarity" (Ontario Ministry of Education 2000, p. 7). Under these guidelines, learning expectations were enlarged and required students to apply a combination of skills to complete learning activities. This kind of outcomes- or competence-based student learning required teachers to begin to employ a "backward design" (Richards 2013) approach to teaching, which starts with the learning outcome, from which lessons and activities are then constructed to guide students to successful attainment of the expectations (Richards and Rodgers 2014). Successful completion of an FSL course under these guidelines was achieved through the students' demonstrated oral and written literacy in French with a strong emphasis on grammatical accuracy.

In contrast, the expectations of the most-recent Ontario Ministry of Education FSL curriculum guidelines introduced in 2013-2014 (Ontario Ministry of Education 2013, 2014) are informed by the Common European Framework of Reference for Languages (CEFR) (Council of Europe 2001). The CEFR provides "a common basis for the elaboration of language syllabuses, curriculum guidelines, examinations, textbooks, etc." (Council of Europe, p. 1). The CEFR provides a series of standardized descriptors which are used to evaluate competences in foreign languages across five activities (reading, writing, listening, spoken interaction, and spoken production) at six achievement levels. The descriptors for each activity are written as "Can do" statements and include a description of what L2 learners "can do" in the target language at the various levels of proficiency. The CEFR is descriptive as opposed to prescriptive and therefore "the framework is designed to be flexible and practitioners are encouraged to adapt it across various L2 educational contexts" (Faez et al. 2011b, p. 5). Although extensively used in Europe for over two decades, the adaptation of the CEFR to educational contexts in Canada is more recent, with widespread interest only in the last ten years or so (Arnott et al. 2017). CEFR-informed teaching and learning emphasizes language production through interaction (Piccardo 2013). Ontario's current FSL curriculum documents, informed by the CEFR, promote the creation of an action-oriented learning environment in the classroom in which students learn through meaningful interactive tasks based in real-world, everyday contexts. The current documents start from the perspective that "communicative and action-oriented approaches to teaching French put meaningful and authentic communication at the centre of all learning activities" (Ontario Ministry of Education 2014, p. 9). This emphasis on authentic and meaningful interaction shifts the teaching of FSL away from presenting language "as a system of disconnected and isolated components" (Ontario Ministry of Education 2014, p. 9) and aims to focus FSL learners "on what it is they are trying to communicate; what they need others to understand, and why" (Ontario Ministry of Education 2014, p. 7). Under these guidelines, "language instruction must provide significant levels of meaningful communication and interactive feedback in the target language so that students can develop both language proficiency and cultural understanding" (Ontario Ministry of Education 2014, p. 9). The expectations of the current documents stress oral communication (listening and speaking), which is viewed as essential to second language (L2) acquisition. While both the previous and current documents encourage a balance of interconnected skills development (listening, speaking, reading, and writing), the current curriculum focuses classroom practice on the introduction of language that is relevant to 
students' communication needs and the practice of language skills through interaction that is meaningful to students. The expectations of the current FSL curriculum signal a shift away from a cognitive-based approach to L2 teaching and learning with a heavy emphasis on the mastery of grade-specific grammatical structures. The goals of the new curriculum reach beyond this cognitive model: while "students need to acquire a strong foundation in the French language" they must "focus on communicating in French" (Ontario Ministry of Education 2014, p. 6). Therefore, FSL teachers find themselves in a position of needing to adopt a socio-culturally-informed approach to teaching in which language is presented in context and through tasks that are interactive and useful to language learners in their everyday lives.

In recent years, the Diplôme d'études en langue française: for beginners and intermediatelevel learners (DELF), the FSL proficiency exam aligned with the CEFR, has been administered in many Ontario schools, in partnership with local educational authorities, to Grade 12 students in their final year of schooling as a means to capture their proficiency at the end of their FSL studies. The DELF exam, developed in France by the Centre International d'Études Pédagogiques, tests and certifies the French language skills of non-native speakers through examinations that "have been designed to reflect the principle of action used by the Common European Framework of Reference for Languages, which defines users of a language as social actors who have tasks to perform (that are not only linguistic) in given circumstances, in a given environment and within a specific area of action, which may be personal, public, academic or professional" (Centre International d'Etudes Pédagogiques CIEP 2021). Since 2005, the expectations of the DELF have been consistent with those of the CEFR, and different versions of the exam have been made available around the world in order to meet the needs of a wide range of French-language learners, both school-age and adult (Vandergrift 2012). There are six independent DELF diplomas and each diploma corresponds to one of the six levels of the CEFR: A1, A2, B1, B2, C1, and C2. Recognized in 175 countries, the DELF is the official French-language diploma awarded by France's Ministry of National Education to recognize success at the A and B levels. Level A recognizes basic user proficiency, while Level B recognizes independent user ability. At each level, a series of examinations evaluates all four language skills. Each skill is weighted equally for a total of 100 points for each exam. In order to obtain the diploma, a student must obtain at least 50 points, with a minimum of 5 out of 25 for each skill (Vandergrift 2012). As described on DestinatiONtario DestinatiONtario DELF (2021), an information site for Ontario FSL students and their parents that is funded by the Ontario Ministry of Education and the Government of Canada through the Department of Canadian Heritage, when administered in Ontario's school boards, DELF testing procedures are strictly observed to ensure test security and diploma credibility. The teachers from these boards who act as examiners and markers must complete training conducted by authorized instructors and must recertify every five years. The monitoring of exam materials is maintained to ensure that the DELF continues to be recognized by the Association of Language Testers in Europe. Ontario students taking the exam do so above and beyond the requirements of their FSL programs and may choose to attempt any level of the exam they feel is appropriate to their abilities; however, they must decide well beforehand the level of the DELF they wish to challenge.

Set within this context of changing FSL orientations, the present exploratory article describes the self-reported instructional practices of a group of early-CEFR-adopter FSL teachers in Ontario as they think retrospectively about their practices before having engaged in intensive and extensive CEFR-related professional learning experiences versus their reports of their current practices after their professional learning. It also describes the areas of strength and opportunities for proficiency improvement, measured through the CEFR-aligned DELF exam, of a group of highly-motivated Grade 12 Ontario learners who have continued with their learning of French beyond the mandatory years and who are now preparing to graduate from their FSL studies, which were undertaken under the former curriculum guidelines (i.e., before the introduction of the CEFR-informed, task-based 
documents). In looking across the findings for these two groups, the article concludes by considering how the CEFR is impacting the local landscape of FSL education in Ontario.

\section{Literature Review}

The CEFR's action-oriented approach, which emphasizes language production through interaction (Piccardo 2013), lends itself nicely to a task-based approach to language teaching (Little 2006). As Piccardo (2014, p. 28) explains, "the action-oriented task seeks to break down the walls of the classroom and connect it with the outside world." The DELF exam structure also draws heavily on the use of interactive tasks based in real-world, everyday contexts, as do Ontario's current CEFR-informed FSL guidelines, which rely on such meaningful tasks in order to put authentic communication at the center of all classroom teaching and learning. Thus, in looking to understand how the CEFR is impacting Ontario FSL education, it is first important to clarify what is meant by a task-based approach to language teaching, particularly as viewed in an action-oriented approach.

\subsection{Task-Based Language Teaching from an Action-Oriented Approach}

Task-based language teaching differs from traditional language teaching approaches in that it emphasizes the need to engage learners through tasks where the primary focus is on real-world communication, while still drawing learners' attention to the forms needed to successfully carry out the task (Long 2014). Tasks that use language beyond the confines of the classroom are what Long $(1985$, p. 89), in his seminal work, referred to as targeted tasks, that is "a piece of work undertaken for oneself or for others [ ... ] the hundred and one things people do in everyday life, at work, at play and in between." The goal of such tasks is not linguistic but rather functional and communicative. When such tasks are brought into the classroom, they become pedagogical tasks. As Nunan (2004, p. 4) explains, a pedagogical task is "a piece of classroom work that involves learners in comprehending, manipulating, producing or interacting in the target language while their attention is focused on mobilizing their grammatical knowledge in order to express meaning, and in which the intention is to convey meaning rather than to manipulate form." What is important here is that such tasks require the learner to put into action their grammatical knowledge to accomplish a goal linked to real-world communication. Realworld communication, as explained in Halliday's (1985) influential early work, can serve a number of intertwined purposes, including a transactional or service macrofunction (e.g., exchanging goods and services), an interpersonal or social macrofunction (e.g., socializing with others), and an aesthetic macrofunction (e.g., enjoyment). Indeed, different kinds of tasks create opportunities for different kinds of real-world interactions that foster the processes involved in second language acquisition (Ellis et al. 2019). The kind of real-world communication that tasks envision necessitates the negotiation of meaning and form as interlocutors work to understand each other, express themselves, and accomplish the task at hand. In the classroom, this type of negotiation is achieved through task-based interaction, particularly when accompanied by corrective feedback that draws learners' attention to form as it is used in the service of conveying meaning.

In implementing task-based language teaching, teachers must think carefully about the three task stages outlined by Ellis (2003), namely the pre-task, the main task, and the post-task. The goals of the pre-task, according to Ellis et al. (2019), are to provide learning opportunities that motivate learners by helping them to see the relevance of the task for their own life in the real world and that prepare them for the task by clarifying the procedures and outcomes and by ensuring that they have the schematic and linguistic knowledge necessary to carry out the task. The main task focuses on the successful completion of the task at hand through interaction requiring real-world communication. During the task, teachers encourage learners to focus on form either through pre-emptive interventions (i.e., in anticipation of an error or in response to a form-related request by the learner) or reactively through corrective feedback (i.e., after an error is made). Corrective feedback can be offered by explicit or implicit means and can take the form of recasts, repetition, 
elicitation, clarification requests, metalinguistic clues, and explicit correction (Lyster and Ranta 1997). The post-task provides follow-up learning opportunities by having learners repeat the task (exactly, procedurally, or in terms of its content), by addressing linguistic forms that were problematic for learners during the main task, and by having learners reflect on the task and/or their or others' performance (Ellis et al. 2019).

Task-based language teaching is, thus, clearly different from traditional approaches, like those informing Ontario's previous FSL guidelines, that presented language "as a system of disconnected and isolated components" (Ontario Ministry of Education 2014, p. 9). Instead, a task-based approach, as reflected in Ontario's current CEFR-inspired documents, focuses learners "on what it is they are trying to communicate; what they need others to understand, and why" (Ontario Ministry of Education 2014, p. 7). This is all the more so the case when task-based language teaching is set within an action-oriented approach. As Bourguignon (2010, p. 19-translated from French) explains, in an actionoriented approach, the task "puts the learner into action; it places the learner in the action. The task must make the learner more autonomous as a user of the language. The task must enable the learner to line up needs and a goal to be achieved, by selecting relevant knowledge and useful skills." In this way, as Piccardo (2014) explains, the communicative activities required by tasks are not the goal as such, but rather a means to stimulate genuine interaction among students as they act effectively and autonomously to collaboratively map out a way to accomplish the task, all the while making judgements about what the situation requires and what linguistic and non-linguistic tools they possess to do this. The role of the teacher in this process (Piccardo 2014, p. 31) is to help students "with their strategic approach, notably during the stages that involve planning the task, making decisions, realizing which competences to activate, understanding their strengths and weaknesses, conducting searches, and reflecting on what they have learned, what they are able to do, and how they do it." This understanding of task-based language teaching within an actionoriented approach reveals an "open, dynamic, and evolving vision" (Piccardo 2014, p. 31) of the learner as an active social agent.

\subsection{The CEFR in Canadian FSL Education}

Grounded in an action-oriented approach to task-based language teaching, the CEFR has much to offer Canadian FSL education. Despite this, the adoption of the CEFR in Canada is relatively recent and voluntary (e.g., Arnott et al. 2017; Piccardo et al. 2019) and is making greater inroads in some provinces (e.g., Alberta, British Columbia, Ontario, and New Brunswick) than in others (Arnott 2013)—with education in Canada falling under provincial rather than federal jurisdiction. The impact of the CEFR on FSL education in Ontario and certain other provinces (e.g., Council of Atlantic Ministers of Education and Training 2010; Saskatchewan Ministry of Education 2013) is thanks in large part to the growing popularity of the DELF exam among teachers, students, and parents (Vandergrift 2015). According to Vandergrift (2015), since becoming familiar with the DELF exam, Canadian FSL teachers report having increased the number of interactive speaking activities they use in their teaching and comment on relying more on authentic documents in tasks designed to develop their students' receptive skills. One teacher reported that, in contrast to evaluations focused on assessing the acquisition of isolated grammatical rules, familiarity with the DELF exam has expanded their focus to include the assessment of more contextualized language use. The CEFR's impact on Canadian FSL education is also being felt, according to Moonen et al. (2013), through the use of CEFR-informed textbooks, the adoption of more communicative and competence-based approaches to teaching, a focus on language use and oral skills development, and the encouragement of students to take a more active role in their learning of French.

In two province-wide studies for the Ontario Ministry of Education, Faez et al. (2011a) and Faez et al. (2011b) examined the role and feasibility of implementing the CEFR to improve FSL learning outcomes in the province. FSL teachers in Core French programs and those in French Immersion (i.e., programs where French is the medium of instruction 
through which select subjects are taught) were introduced to the CEFR and to CEFRinformed activities and resources. The participating teachers completed pre- and poststudy questionnaires examining their attitudes towards and their perceptions of the CEFR's action-oriented approach. The FSL teachers reflected positively on the potential they saw in the CEFR's task-based approach to promote students' competences and engagement. They shared that the more practice they had with a task-based approach, the more comfortable they felt incorporating a focus on form within their communicatively-oriented teaching. Faez and her colleagues also conducted individual and focus group interviews with the teachers three months after having introduced them to the CEFR and related materials. The teachers reported that the CEFR-informed instruction that they were using was enhancing their learners' autonomy, motivation, self-confidence, authentic language use, and oral language abilities. Notwithstanding these positive impressions of the CEFR's potential, the teachers also shared concerns about the difficulty of finding time to implement a CEFR-based approach in their teaching and about a lack of broad understanding of the CEFR.

Mui (2015), in a multi-phased case study that included a reflective-practice journaling component, collaborated over the course of five months with a teacher-participant on self-directed professional development aimed at promoting a better understanding of the key principles of the CEFR and how they could inform their Kindergarten (ages 3-5) and Grade 1 (ages 5-6) FSL teaching in keeping with the new CEFR-informed curriculum. Through their intensive and extensive collaboration, the teacher-participant gained a deeper understanding of the complex framework, suggesting that lengthy professional development is a valuable approach that can help teachers see how to adapt descriptors to better meet learner needs. This emphasis on the value of intensive and extensive CEFRrelated professional development supports a recommendation by Majhanovich et al. (2010) that teachers be given such opportunities in order to gain a broad-enough understanding of the CEFR to begin to implement aspects of the framework in their FSL classrooms.

Mison and Jang (2011) found that FSL teachers appreciate the transparency, consistency, and global validity of the CEFR levels and descriptors, while FSL teachers in a study by Piccardo (2013) came to view the framework not solely as an instrument that sets and maintains teaching standards, but also as a tool that allows them to explore their approach to teaching. Concerning FSL students' experiences with the CEFR, Kristmanson et al. (2013) examined Grade 12 students using a language portfolio inspired by the principles and guidelines of the European Language Portfolio. While the students appreciated being able to make choices, use authentic and meaningful material, and have the opportunity to reflect and build their autonomy, some students felt ill-prepared for the type of language practice demanded in a CEFR-informed classroom.

With this theoretical and research base in mind, the current paper draws on teacher and student data to describe how the CEFR is impacting FSL teaching and learning in Ontario. Specifically, the paper responds to the following research questions:

1. What instructional practices do a group of early-CEFR-adopter Ontario FSL teachers retrospectively report having used under Ontario's former curriculum guidelines before having engaged in intensive and extensive CEFR-related professional learning?

2. What strengths and areas for proficiency improvement are evident in the DELF exam results of a group of highly-motivated students as they prepare to graduate from their FSL studies, which took place under Ontario's former FSL guidelines?

3. What changes in instructional practices do these Ontario FSL teachers report using now under the new CEFR-informed guidelines as a result of their intensive and extensive CEFR-related professional learning?

\section{Methods}

To respond to these guiding questions, the current paper draws on FSL teacher and student data from two reports for projects funded by the Government of Ontario and the Government of Canada through the Department of Canadian Heritage and directed by 
Curriculum Services Canada (Rehner 2014, 2017). In the student project, 434 Grade 12 Ontario FSL students took part in the Spring, 2013 DELF exam as part of the Ministry's initiative. This timing is important, as it means that the students' schooling had taken place entirely under the former FSL guidelines (i.e., before the CEFR-informed, task-based documents had been introduced). These students were highly-motivated FSL learners insofar as they had elected to continue their French learning well beyond the point past which FSL courses were mandatory (i.e., up until the end of Grade 9) and insofar as they agreed to challenge the DELF exam above and beyond the requirements of their FSL programs. These students were from Core French, Extended French (i.e., a program offering Core instruction followed by a year or two of Immersion-like instruction), and French Immersion programs across the province. Although it would be of considerable interest to examine the student results according to these program distinctions, the data in the original project do not allow for this type of breakdown, as the DELF exam results were presented as a whole across the programs. The students self-selected the level of the DELF they would challenge. While all administrators and markers were certified DELF examiners from the participating school boards, they were not necessarily the teachers of the student participants. The DELF levels A2, B1, and B2 were challenged by students from each of the three FSL programs (no students elected to challenge the A1 level exam). Those students who challenged the A2 level $(n=84)$ were predominantly from Core French, and the overall success rate was $99 \%$. Those challenging the B1 level $(n=207)$ included a substantial proportion of the students from Extended French, and their success rate was $96 \%$. Finally, the students taking the B2 level exam $(n=143)$ were predominantly from French Immersion, and their success rate was $87 \%$. These high success rates reflect, in part, the special characteristics of this group of students as highly-motivated learners in their final year of study, and also, perhaps, the desire on the part of some of the students to challenge an exam level they felt certain of easily passing, since Core French students are expected to reach the B1 level by the end of their studies (not A2), and Extended French and French Immersion students are expected to reach the B2 level (not B1).

The teacher project focused on 103 FSL teachers from all grade levels (Kindergarten to Grade 12) from across Ontario. The teachers responded to an online-survey in the Spring of 2016 (i.e., shortly after the current CEFR-informed FSL guidelines had been introduced) that tapped their self-reported instructional practices before versus after their engagement in intensive and extensive CEFR-related professional learning. Each participating school board invited five FSL teachers to be part of the project, and, as a result, it is likely that the selected teachers were early adopters of the CEFR and among the most positively oriented to the framework. The online survey asked the teachers to, first, provide background information regarding their teaching experience and their CEFR-related professional learning and, second, to respond to questions focusing on their instructional practices in the areas of planning, classroom delivery, and assessment/evaluation both before and after their CEFR-related learning. In this way, the teachers were asked to think in a retrospective fashion about their prior instructional practices before their professional learning experiences and to report on their current practices after their professional learning. Of the 103 teachers, 37\% taught exclusively in a Core French program, 1\% in Extended French only, $34 \%$ solely in French Immersion, and $28 \%$ in a combination of these program types. However, like in the student project, the data in the report from the teacher project were presented as a whole and, thus, do not allow for an investigation by program type. With respect to their number of years of teaching experience, 17 teachers had taught for 24 years or more, 17 teachers had taught for 20-23 years, 13 teachers for 16-19 years, 19 teachers for 12-15 years, 17 teachers for 8-11 years, 19 teachers for $4-7$ years, and only one teacher reported teaching for 1-3 years. Therefore, with the exception of a few teachers, the vast majority of the respondents had spent the better part of their careers teaching under the curriculum guidelines in place from 1999-2013, and all were grappling with adapting to the new CEFR-informed, task-based FSL documents. Finally, for their CEFR-related professional learning, two thirds of the teachers reported having engaged in such learning 
for one to five years (with $48 \%$ reporting $4-5$ years), while the remaining third of the teachers reported 6 or more years of such professional development. These professional learning opportunities included DELF marker training for all 103 teachers, school- or board-sponsored CEFR conferences or workshops (for 93\% of the teachers), DELF refresher courses $(77 \%)$, job-embedded CEFR learning (56\%), CEFR provincial web-conferences (55\%), and regionally-sponsored CEFR learning events (54\%) among other activities.

All teachers provided their informed consent for inclusion before participating in the teacher project. Informed consent was also obtained from all participating students and their parents before the student project began. The protocols were approved by Curriculum Services Canada (CSC 611-LGY 769). In the student project, the DELF exam scores were analyzed by a university-based statistician using independent and paired tests for equality of means (z/t) (De Veaux et al. 2011), with statistical significance set at 0.05 . In the teacher project, for most survey questions, the teachers indicated their frequency of use of instructional practices on a 0 to 5 -point Likert scale, where 0 represented no use and 5 represented the highest level of use. The analysis of these responses was presented using mean frequencies as indicators of the teachers' central tendencies.

\section{Results}

The teacher and student results are presented below in response to the three research questions guiding the present study, starting with the teachers' retrospective reports of their instructional practices under Ontario's former curriculum guidelines and prior to their CEFR-related professional learning; followed by the proficiency strengths and weaknesses, as identified through DELF exam results, for the students graduating from programs guided by the former curriculum documents; and ending with the changes in instructional practices reported by the teachers under the current CEFR-informed guidelines and as a result of their CEFR-based professional learning.

\subsection{Teachers' Retrospective Reports of Instructional Practices Prior to Their CEFR-Related Professional Learning}

The teachers were asked to think retrospectively about the planning, classroom delivery, and assessment/evaluation practices they had used under the former Ontario FSL guidelines in the years prior to having engaged in any CEFR-related professional learning. With respect to planning, in commenting on the percentage of class time they usually planned to allot to each of the four language skills, the teachers reported that the majority of their instructional time (32\%) focused on activities addressing writing skills, while both reading and speaking skills were allotted an equal amount of class time (25\%), with listening skills receiving the smallest portion (18\%) of the teachers' reported instructional focus. This privileged focus on writing in the teachers' reported practices is reflective of the curriculum documents in place at that time which targeted the skills that learners need to become "good writers who are able to communicate ideas and opinions with ease and clarity" (Ontario Ministry of Education 2000, p. 7). The teachers' reported planning practices before their CEFR-related professional learning also focused most often on the building of linguistic competence (e.g., grammar, pronunciation, word choice) and pragmatic competence (e.g., organization of ideas, purposeful communication), as well as on engaging students in individualized tasks that had been designed to meet the needs of students who might be at different levels of FSL proficiency (see Figure 1). 


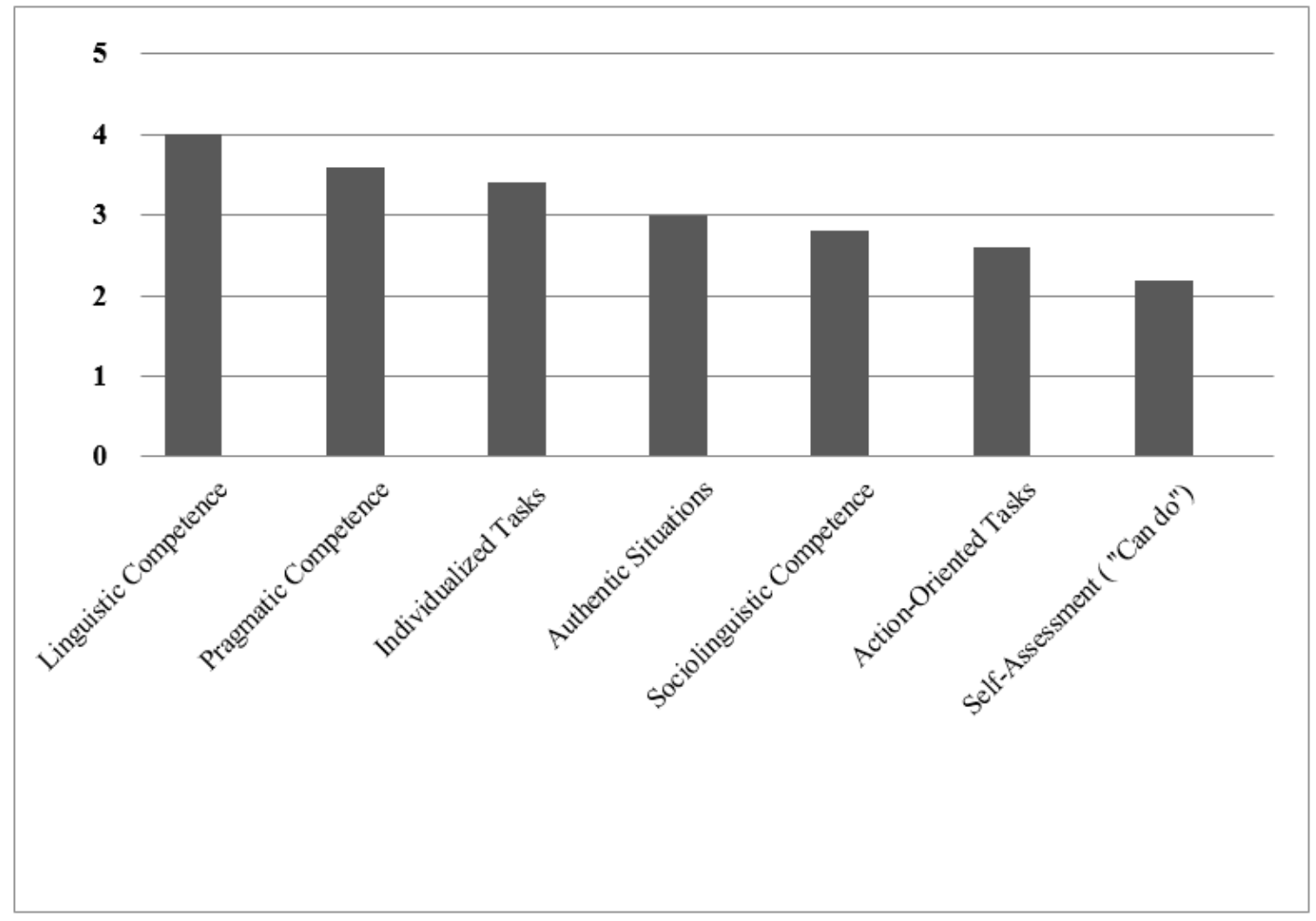

Figure 1. Frequency of Using Instructional Practices before Professional Learning.

In considering their classroom delivery before their professional learning, the teachers were asked to report retrospectively on their frequency of use of various teaching practices, including a focus on language structures, the correction of student errors as they occurred, oral interaction and written activities related to everyday life, teaching and learning organized around real-life situations, encouraging students to identify competences that they need to carry out a task, and the use of a language portfolio to track students' development. As Figure 2 shows, the teachers' reported practices before their CEFR-related professional learning focused, above all, on teaching language structures and correcting student errors as they occurred. The teachers also reported paying less attention to oral interaction and written activities related to everyday life and to teaching and learning organized around real-life situations. This strong focus on grammatical accuracy with less attention to reallife uses of language were in line with the FSL guidelines in place at that time which emphasized the mastery of grade-specific grammatical structures through the completion of learning activities targeting oral and written literacy. Encouraging students to identify competences that they needed to carry out a task and the use of a language portfolio to track students' development were the least-frequently-reported strategies. When reflecting on their classroom delivery related to the development of the receptive skills of listening and reading and the productive skills of speaking and writing (see Figure 3), the teachers reported placing the greatest emphasis on linguistic competence and less emphasis on pragmatic competence and sociolinguistic competence (e.g., level of formality, politeness conventions). The teachers were also asked to reflect on how they presented language in the classroom prior to their CEFR-related professional learning. Forty-eight percent of the teachers reported presenting language in "isolated or disconnected ways," and 41\% reported "using themes, mainly focusing on vocabulary" (see Figure 4). Again, this focus on forms in isolation and the use of themes to direct vocabulary teaching were consistent with the FSL curriculum guidelines in place at that time. 


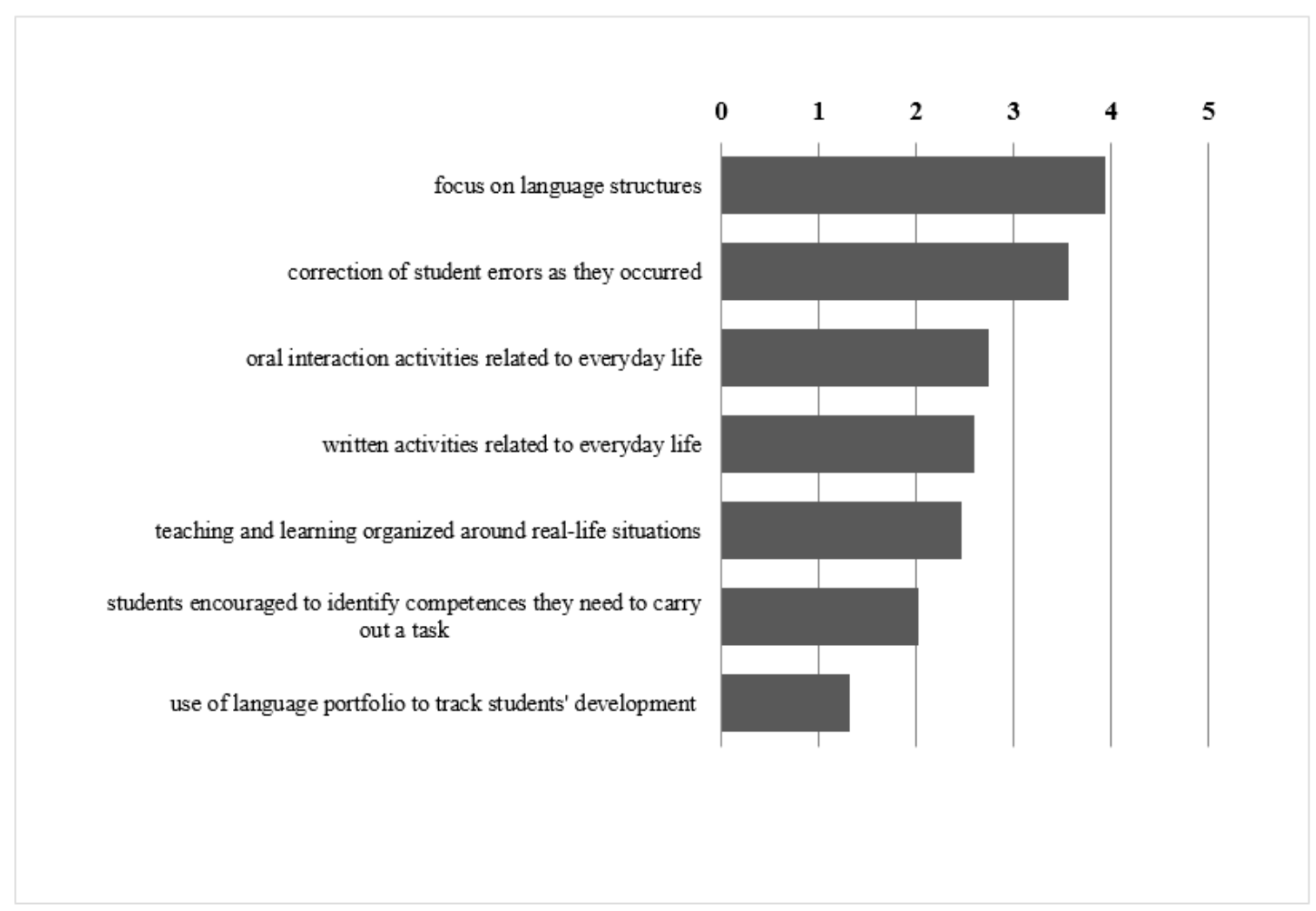

Figure 2. Frequency (0-5) of Practices before Professional Learning.

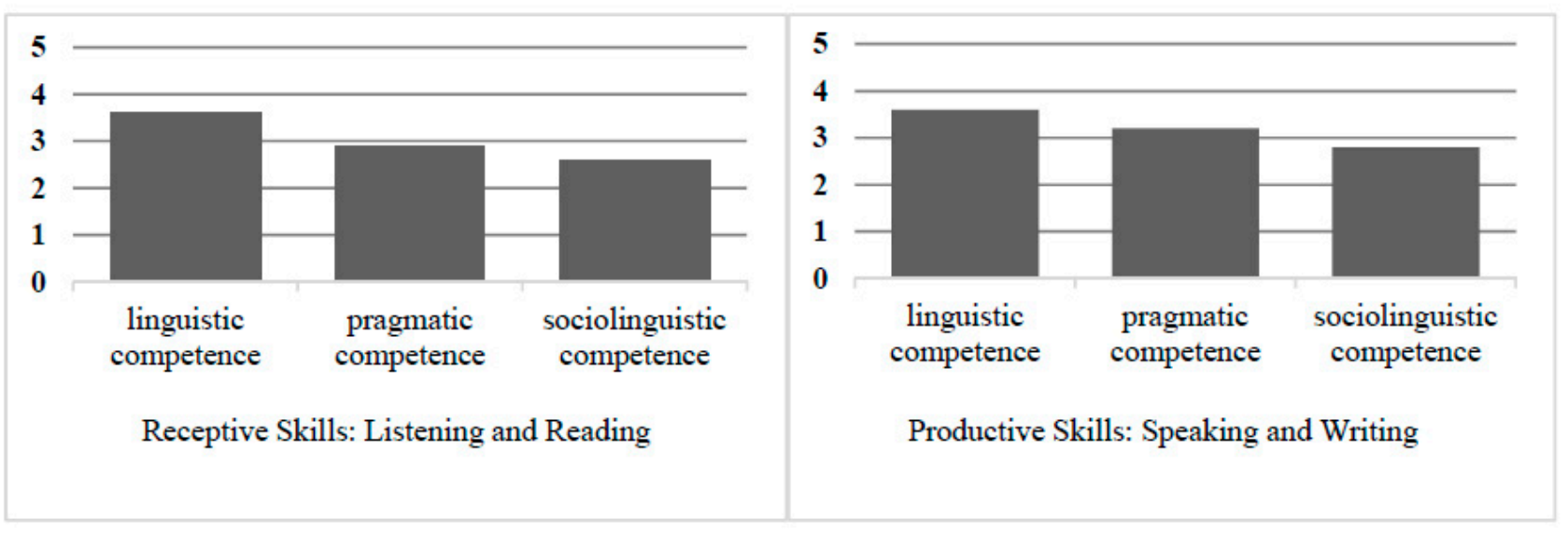

Figure 3. Emphasis (0-5) on Competences in Receptive and Productive Skills before Professional Learning.

With respect to their retrospective reflections on their assessment and evaluation practices prior to their CEFR-related professional learning (see Figure 5), the teachers reported focusing both their criteria and feedback on form over function. Above all, the teachers reported concentrating on assessing grammatical accuracy and orthographic control. They also reported evaluating phonological control and control of vocabulary but paying less attention to assessing vocabulary range, coherence/cohesion, fluency, and functional competence. Consistent with their classroom delivery, more attention in their feedback on students' work was reportedly given to structural precision, with less to pragmatic and sociolinguistic appropriateness. Finally, the teachers were asked to indicate the percentage of attention they had allotted to each skill in their summative evaluations before their CEFR-related professional learning. The teachers reported devoting $60 \%$ of their evaluations to the written skills and only $40 \%$ to the oral skills. This was consistent 
with the teachers' reported planning practices in which writing and reading were allotted a combined $57 \%$ of instructional time, with only $43 \%$ devoted to listening and speaking.

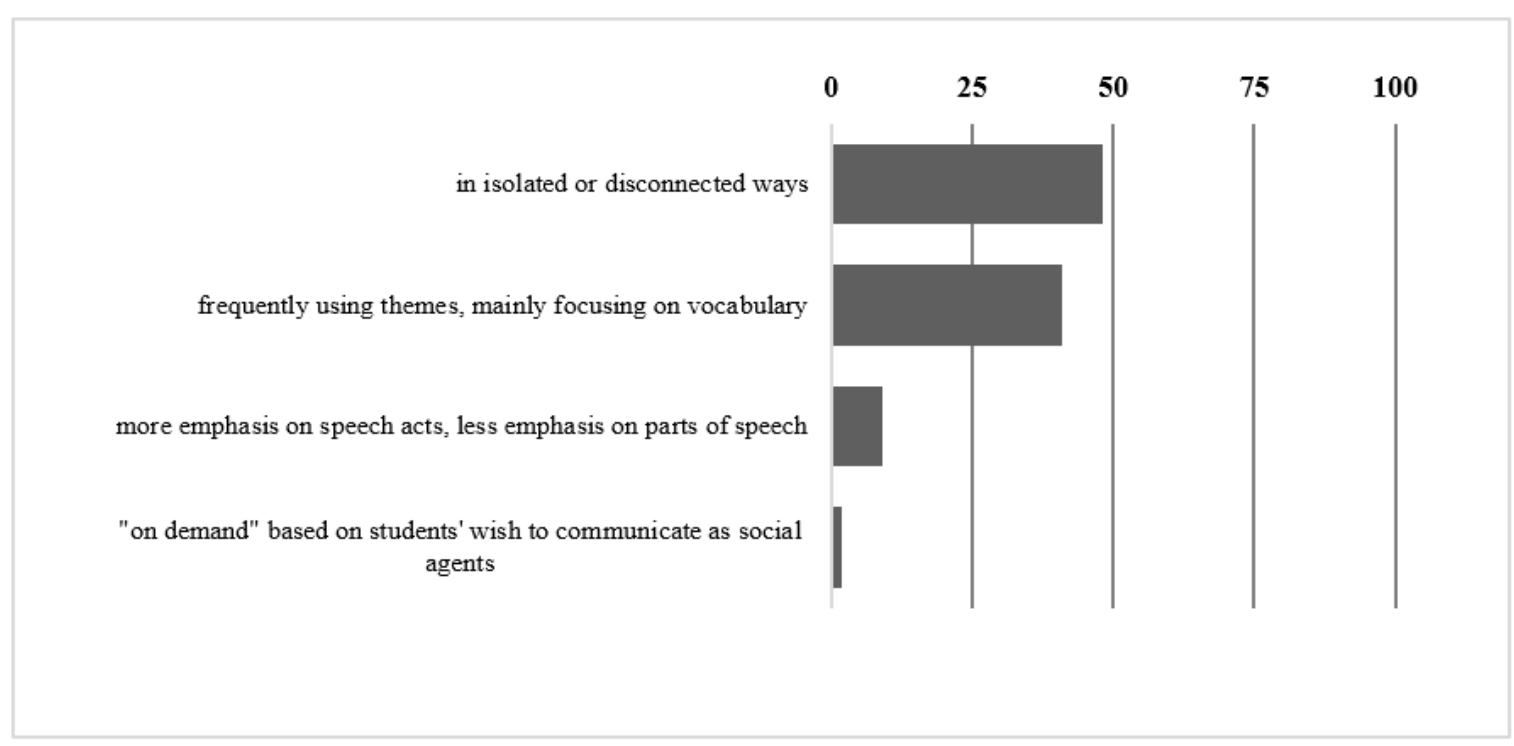

Figure 4. Presentation of Language (\%) before Professional Learning.

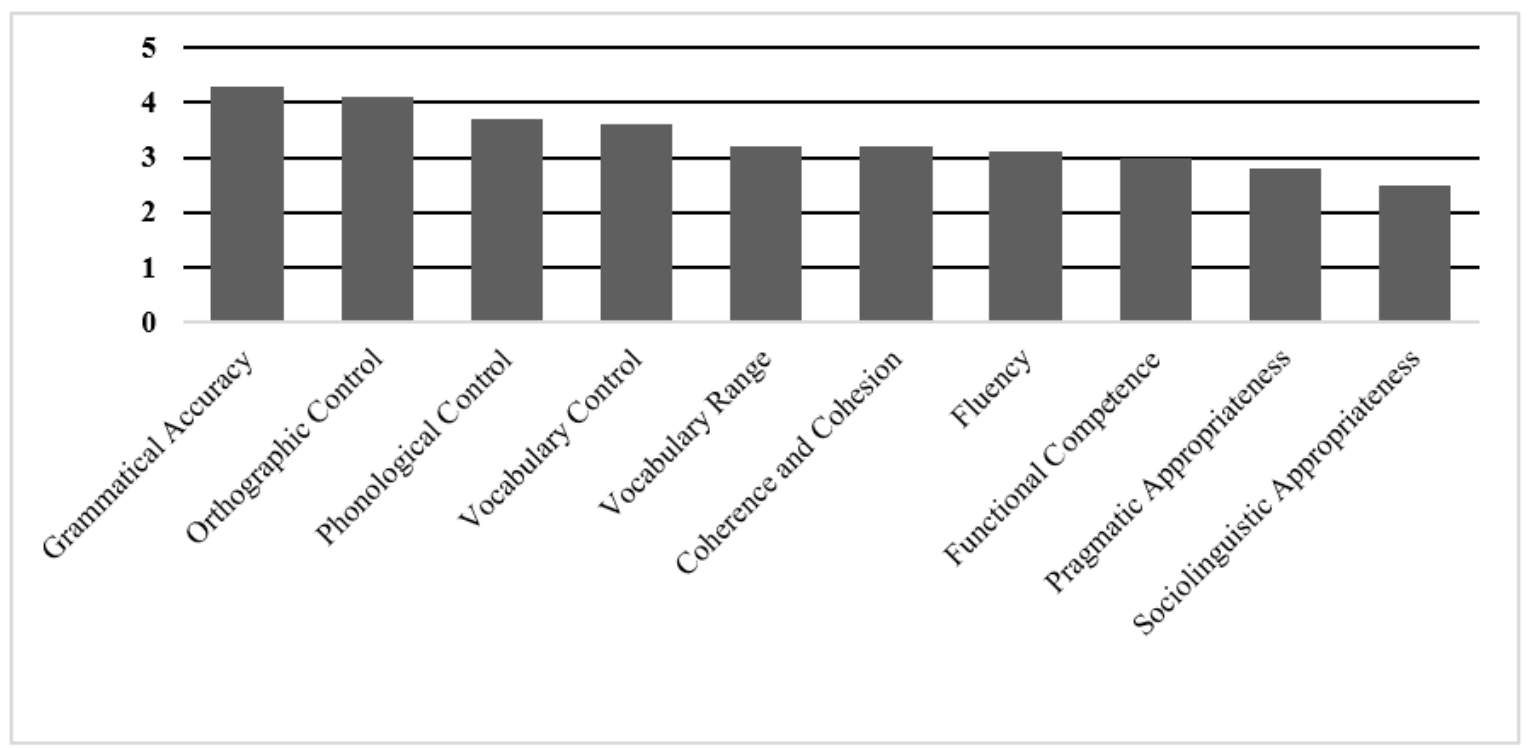

Figure 5. Frequency (0-5) of Targeting Aspects of Students' Work before Professional Learning.

In sum, the teachers' retrospective reports of their instructional practices prior to their CEFR-related professional learning reveal planning, teaching, and assessment/evaluation strategies which focused on structural precision, with stress on specific structures in isolation and on thematic vocabulary supporting the accomplishment of individualized tasks designed to address learners' varying FSL proficiency levels. This preference for a "form over function" approach was also evident in the teachers' reported assessment criteria and feedback. Further, the teachers reported prioritizing class time for written skills development over oral competence. These instructional practices reported by the teachers were reflective of the focus of the 1999-2013 curriculum documents in place at that time which promoted grammatical learning and theme-based vocabulary. Under these guidelines, what was taught and how students demonstrated language competence were 
determined by the structures and vocabulary deemed necessary to accomplish pre-selected individualized tasks—-tasks not necessarily requiring language use in real-life contexts.

4.2. Strengths/Opportunities for Improvement in the DELF Results for Students under the Former Guidelines

The DELF exam results provide one means of capturing areas of strength and opportunities for proficiency improvement for the students as they prepared to graduate from their FSL studies, which were undertaken under the former Ontario guidelines (i.e., before the introduction of the CEFR-informed documents). Figure 6 captures the students' overall DELF results. As can be seen, the students scored highest on the reading component with a mean score of $18.98 / 25(76 \%)$, a score which was statistically significantly higher than for all of the other skills ( $p<0.005$ compared to writing, $p<0.005$ compared to speaking, and $p<0.005$ compared to listening). The students' mean score for speaking was 17.33/25 $(69 \%)$, which was statistically significantly lower than reading $(p<0.005)$, but higher than the remaining two skill areas $(p=0.011$ compared to listening and $p=0.042$ compared to writing). Writing, with a mean score of $16.89 / 25$ (68\%), and listening, with a mean score of $16.75 / 25(67 \%)$, were the skills that offered the students the most room for improvement, as they were statistically significantly lower than reading ( $p<0.005$ for both) and speaking $(p=0.042$ and $p=0.011$, respectively), but not statistically significantly different from each other $(p=0.542)$.

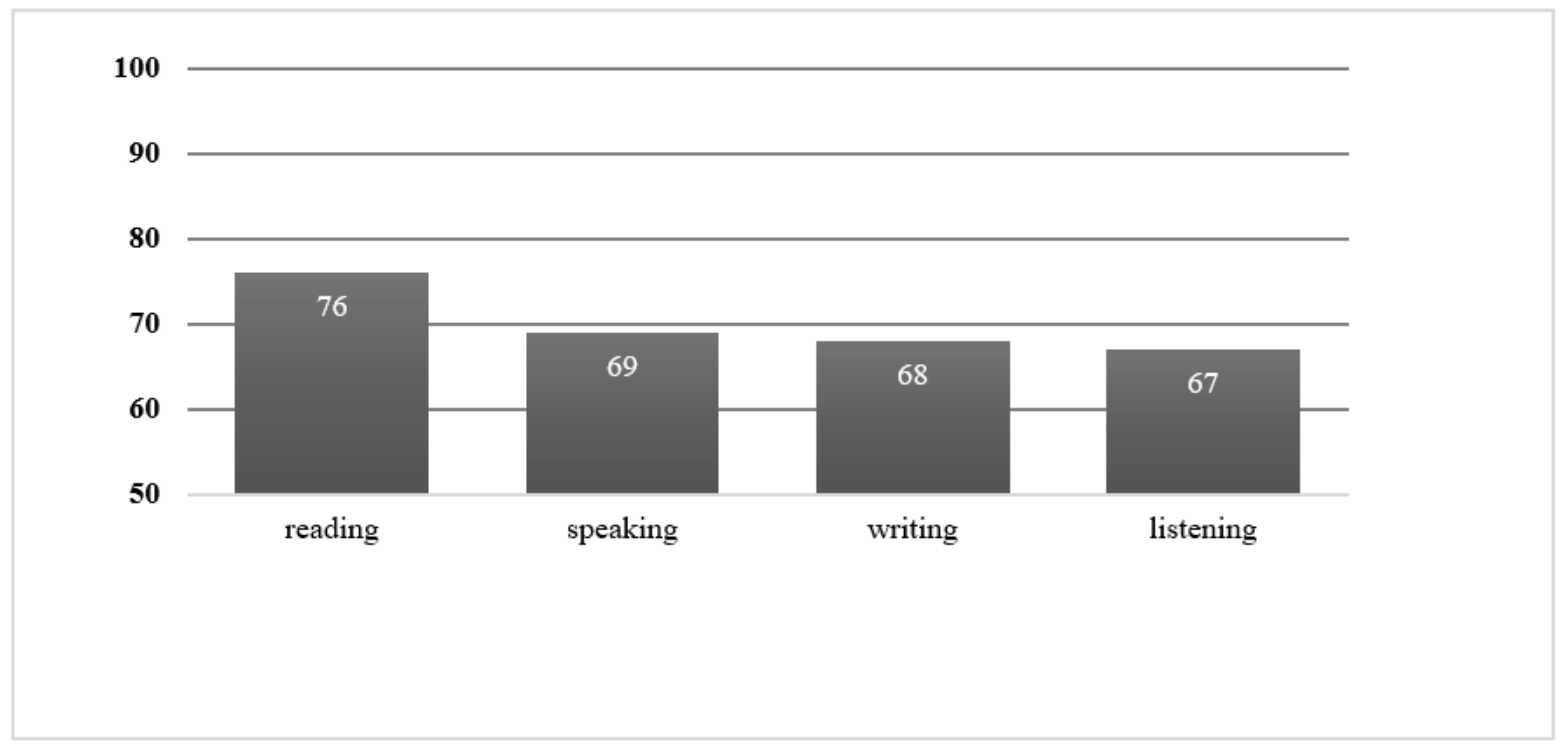

Figure 6. Performance (\%) on the Diplôme d'études en langue française (DELF) by Skill Area for All Groups Combined.

Looking level by level, while reading remained the area of greatest strength regardless of the DELF level the students challenged, the overall scores mask interesting differences. Starting with the results for the A2 exam (see Figure 7), the mean scores were 22.95/25 (92\%) for reading, followed by 18.89/25 (76\%) for listening, 18.88/25 (76\%) for speaking, and $18.54 / 25(74 \%)$ for writing. The score for reading was statistically significantly higher than for the remaining skills $(p<0.005$ for listening, $p<0.005$ for speaking, and $p<0.005$ for writing), with no significant differences among the other skills. For those students who challenged level B1 (see Figure 8), the mean scores were 19.46/25 (78\%) for reading, $17.78 / 25$ (71\%) for writing, 17.66/25 (71\%) for speaking, and 16.90/25 (68\%) for listening. The score for reading was statistically significantly higher than for the remaining skills ( $p<0.005$ for listening, $p<0.005$ for speaking, and $p<0.005$ for writing), while the score for listening was significantly lower than the other three skills ( $p<0.005$ for reading, $p=0.035$ for writing, and $p=0.019$ for writing). The scores for writing and speaking were not significantly different from each other $(p=0.697)$. Finally, for those students 
who challenged level B2 (see Figure 9), the highest mean scores were 15.96/25 (64\%) for speaking and 15.92/25 (64\%) for reading, while the students scored 15.25/25 (61\%) for listening and 14.63/25 (59\%) for writing. The score for writing was significantly lower than the score for the top two skills ( $p=0.003$ reading, $p=0.001$ speaking), but not significantly lower than the score listening $(p=0.141)$.

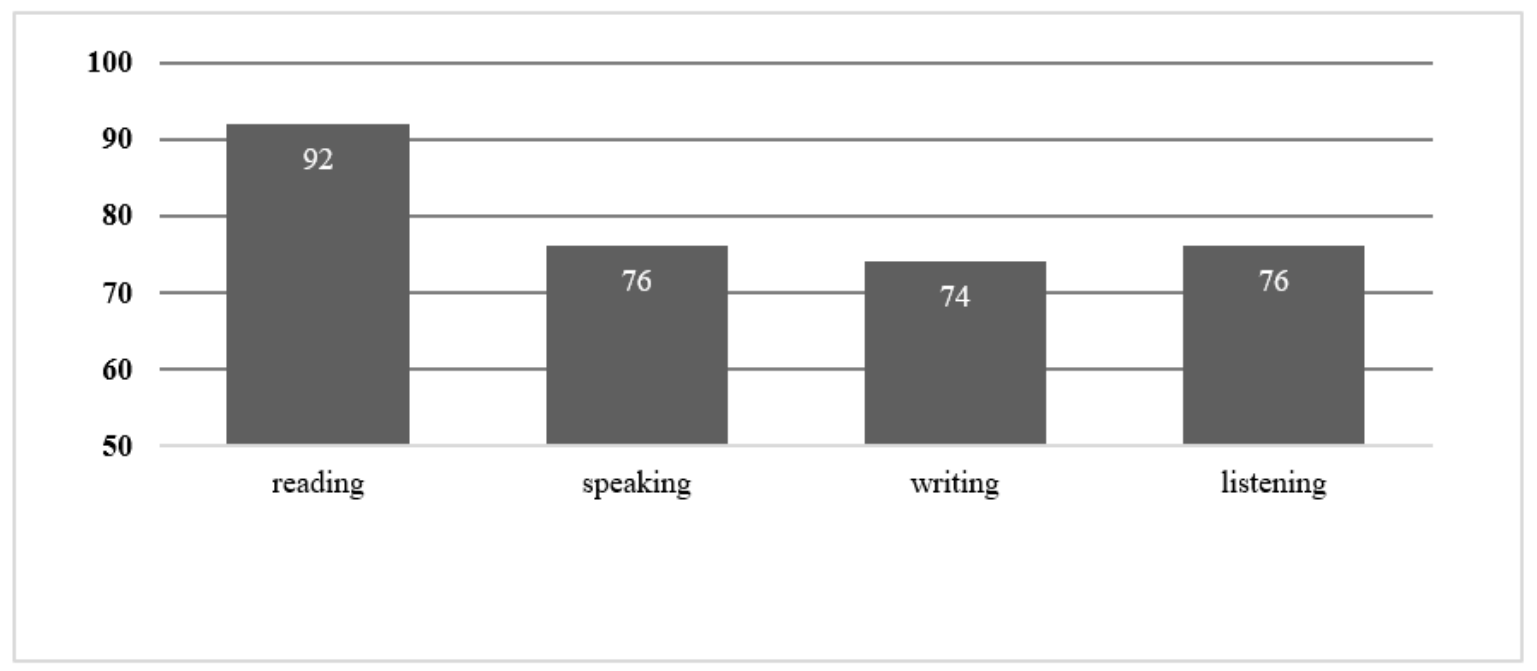

Figure 7. Performance (\%) on the DELF by Skill Area for the A2 Group.

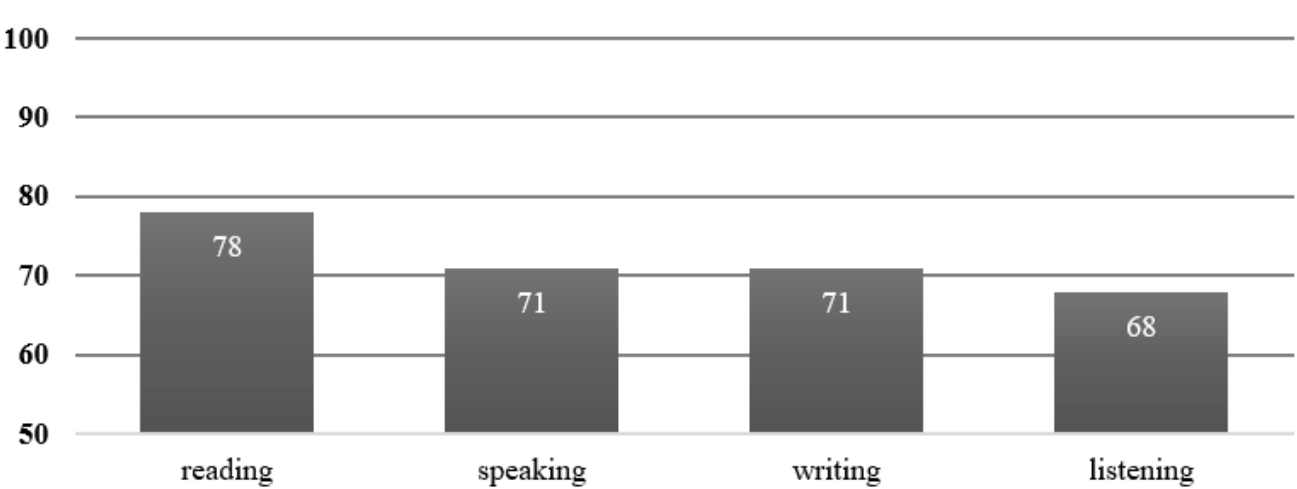

Figure 8. Performance (\%) on the DELF by Skill Area for the B1 Group.

With respect to the specific written and oral subskills that were evaluated as part of the DELF exams' speaking and writing components, the results presented in Table 1 show that, regardless of the exam level challenged, the students' relative strengths for writing included following the task instructions and describing or presenting information, and for the oral they included phonological accuracy and the ability to respond and/or share precise ideas. In contrast, regardless of the exam level challenged, the students struggled more with their use of grammar and vocabulary in both written and oral forms. This was reflected in the low writing and oral scores for morphosyntax (writing-A2 $=62 \%$, $\mathrm{B} 1=51 \%$, B2 $=46 \%$; oral-A2 $=68 \%$, B1 $=62 \%$, B2 $=40 \%$ ) and for vocabulary (writing$\mathrm{A} 2=73 \%, \mathrm{~B} 1=64 \%, \mathrm{~B} 2=53 \%$; oral-A2 $=72 \%, \mathrm{~B} 1=68 \%, \mathrm{~B} 2=40 \%$ ). 


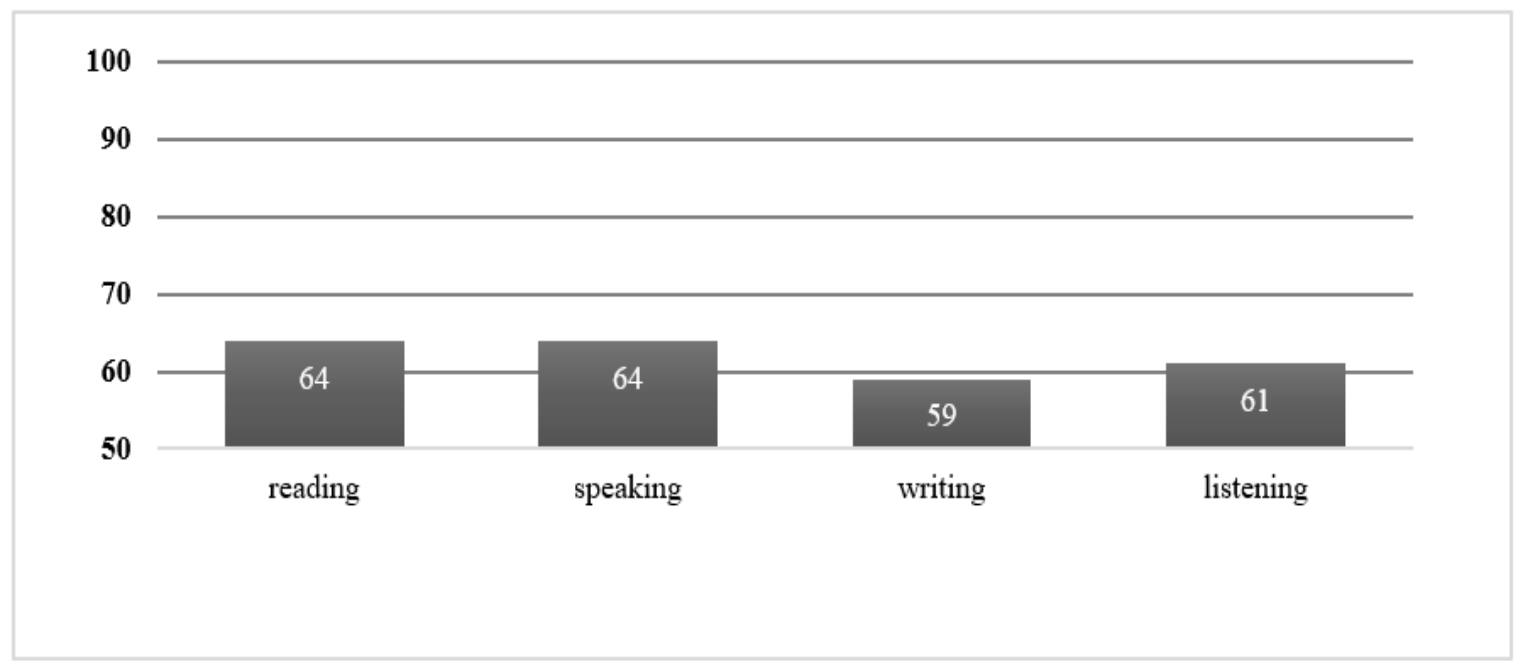

Figure 9. Performance (\%) on the DELF by Skill Area for the B2 Group.

Table 1. DELF Scores by Level for Written and Oral Sub-skills.

\begin{tabular}{|c|c|c|c|c|c|c|c|}
\hline \multirow{2}{*}{ Written Sub-Skills } & \multicolumn{3}{|c|}{$\begin{array}{l}\text { Scores } \\
(x / 100)\end{array}$} & \multirow{2}{*}{ Oral Sub-Skills } & \multicolumn{3}{|c|}{$\begin{array}{l}\text { Scores } \\
(x / 100)\end{array}$} \\
\hline & A2 & B1 & B2 & & A2 & B1 & B2 \\
\hline Follow Instructions & 92 & 87 & 80 & Phonology & 80 & 75 & 53 \\
\hline Describe/Present Info & 78 & 76 & 63 & Respond/Share Precise Ideas & 89 & 71 & 42 \\
\hline Coherence & 77 & 76 & 59 & Present Topic/Own View & 76 & 75 & 42 \\
\hline Vocabulary & 73 & 64 & 53 & Vocabulary & 72 & 68 & 40 \\
\hline Morphosyntax/forms & 62 & 51 & 46 & Morphosyntax & 68 & 62 & 40 \\
\hline
\end{tabular}

Taken together, the DELF exam results reveal that the students were stronger in their written skills than in their oral skills. However, their writing was evaluated more favorably for its coherence than for the accuracy of its grammatical structures or of its use of appropriate vocabulary in context. For speaking, the DELF results showed similar weaknesses in the students' control of grammatical forms and vocabulary. Thus, despite being highly-motivated learners at the end of their FSL studies, the students still faced challenges in deploying their grammatical and lexical knowledge to accomplish the types of interactive and mediated tasks demanded in the DELF - the kinds of tasks that the current CEFR-informed, task-based Ontario FSL guidelines will now be requiring of students. These difficulties are reminiscent of those found by Kristmanson et al. (2013), who showed that some of the Canadian Grade 12 FSL students in their research felt ill-prepared for the type of language practice demanded in CEFR-informed contexts.

\subsection{Changes in Teachers' Reported Practices under the Current Guidelines and after CEFR-Related Learning}

When asked to report on the instructional practices they now use under the current Ontario FSL guidelines and after having engaged in intensive and extensive CEFR-related professional learning, the teachers' responses showed marked changes in all three areas tapped by the survey, namely planning, classroom delivery, and assessment/evaluation. Starting with planning, when considering their planned allotment of class time for each skill area, the teachers reported that they now prioritize speaking (37\% of planned time allotment) and listening (24\%), with less time now allotted to writing (20\%) and reading $(19 \%)$, which marked a shift from their former focus on the written skills (57\%) over the oral skills (43\%). This finding is in line with that of Vandergrift (2015), who found that Canadian FSL teachers reported using more interactive speaking activities as a result of learning more about the DELF, and with the findings of Moonen et al. (2013), who showed that the CEFR is increasing Canadian FSL teachers' focus on oral skills development. The 
teachers' reported planning practices after their professional learning also showed notable changes (see Figure 10). Compared to their previous focus on linguistic competence, pragmatic competence, and individualized tasks, the teachers reported now planning for a focus above all on action-oriented tasks and authentic situations. The attention they reported paying to linguistic competence in their planning was now in line with their focus on both pragmatic and sociolinguistic competences. These reported shifts are not only in line with the current CEFR-informed FSL curriculum documents highlighting "communicative and action-oriented approaches to teaching French [that] put meaningful and authentic communication at the centre of all learning activities" (Ontario Ministry of Education 2014, p. 9), but also with the focus of task-based language teaching that emphasizes the successful completion of tasks through interaction requiring real-world communication (Ellis et al. 2019), where students' attention is focused on "mobilizing their grammatical knowledge in order to express meaning, and in which the intention is to convey meaning rather than to manipulate form" Nunan (2004, p. 4). Remembering, however, that these teachers were hand-selected by their boards to participate in the study, it would be important to consider whether the impact of such professional learning on teachers' planning practices would be similar in a broader sampling of teachers, particularly those with less-positive orientations to the CEFR or those working in provinces where the framework had received less Ministry support.

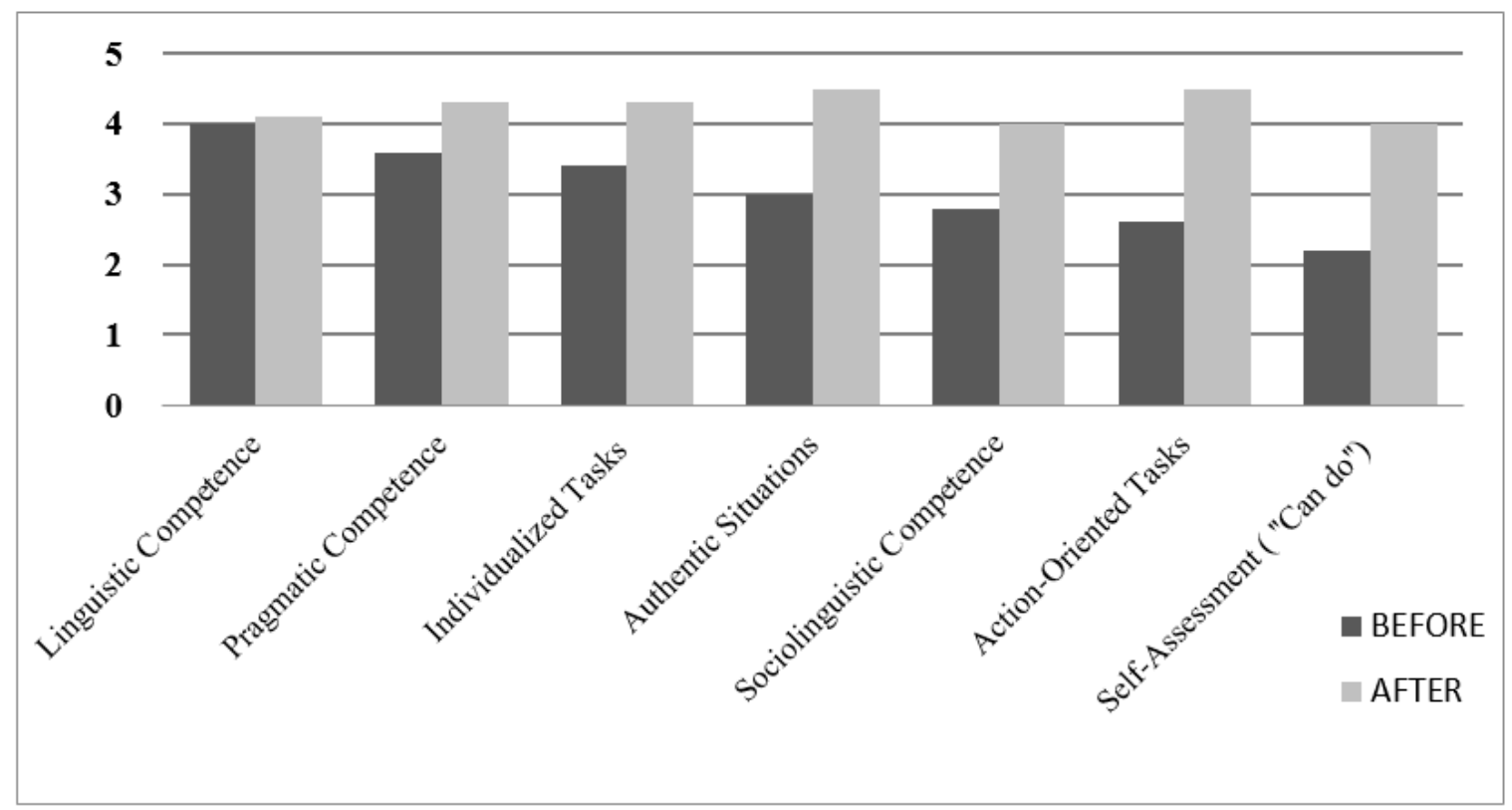

Figure 10. Frequency of Using Instructional Practices before vs. after Professional Learning.

When identifying their priorities for classroom delivery after their CEFR-related professional learning (see Figure 11), the teachers reported shifting their focus away from their previous attention to language structures and error correction above all and towards the importance of situating such a focus within teaching that now emphasizes everyday real-life situations, whether that be in relation to their organizing principles, oral interaction activities, or written activities. They also reported now focusing more on encouraging students to identify the competences that they need to carry out particular tasks. These changes are very much in line with a CEFR-informed, action-oriented approach to taskbased language teaching which, as Piccardo (2014) explained, involves supporting students as they make judgements about what linguistic and non-linguistic tools they need to accomplish the communicative activities that real-world interactive tasks require. This change in focus to more contextualized language use after their professional learning was also evident in the teachers' responses to questions about their focus when addressing 
the development of receptive and productive skills (see Figure 12). While linguistic, pragmatic, and sociolinguistic competences all saw an increase, the most notable changes, in keeping with their reported planning practices, were in the teachers' reported increase in focus on sociolinguistic and pragmatic competences. Although linguistic competence still maintained the highest teacher priority, these reported changes resulted in a more-balanced emphasis across all three competences. An even more dramatic shift was revealed when the teachers were asked to reflect on how they now presented language in the classroom after their CEFR-informed professional learning (see Figure 13). Recall that, prior to their professional learning, an overwhelming number of teachers $(89 \%)$ reported presenting language either in "isolated or disconnected ways" or "using themes, mainly focusing on vocabulary." Strikingly, after their professional learning, $46 \%$ of the teachers reported "more emphasis on speech acts" and $45 \%$ reported presenting language "on demand, based on what students wished to communicate as social agents." No teacher reported continuing the practice of presenting language in "isolated or disconnected ways." This reported emphasis on presenting language within the context of speech acts and students' communicative needs resulting from their actions as social agents is very much in keeping with the emphasis in the current FSL guidelines on authentic and meaningful interaction that shifts teaching away from the presentation of language "as a system of disconnected and isolated components" (Ontario Ministry of Education 2014, p. 9) and that aims, instead, to focus FSL learners "on what it is they are trying to communicate; what they need others to understand, and why" (Ontario Ministry of Education 2014, p. 7). It is also very much in line with the goal of task-based language teaching within an action-oriented approach, which seeks to embed a focus on form within real-world communication that is needed for the type of interaction which takes place within carefully designed pedagogical tasks (Long 2014). Recall that the work by Faez and her colleagues (Faez et al. 2011a; Faez et al. 2011b) also showed that the more practice FSL teachers had with the type of task-based approach at the heart of the CEFR, the more comfortable they were incorporating a focus on form within their communicatively-oriented teaching. However, again, how teachers in other contexts or with less-positive orientations to the CEFR might react is not known.

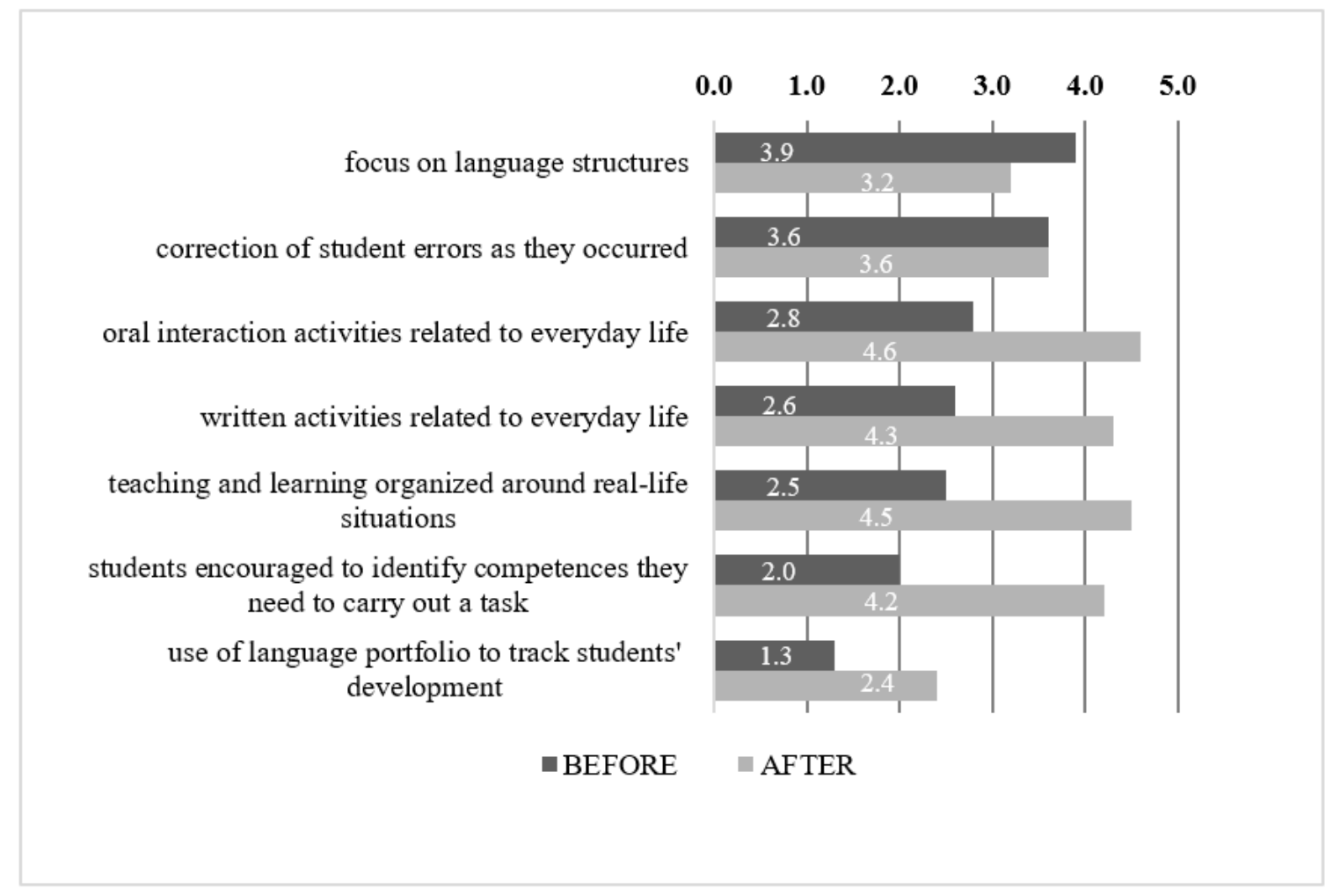

Figure 11. Frequency (0-5) of Teacher Practices before vs. after Professional Learning. 


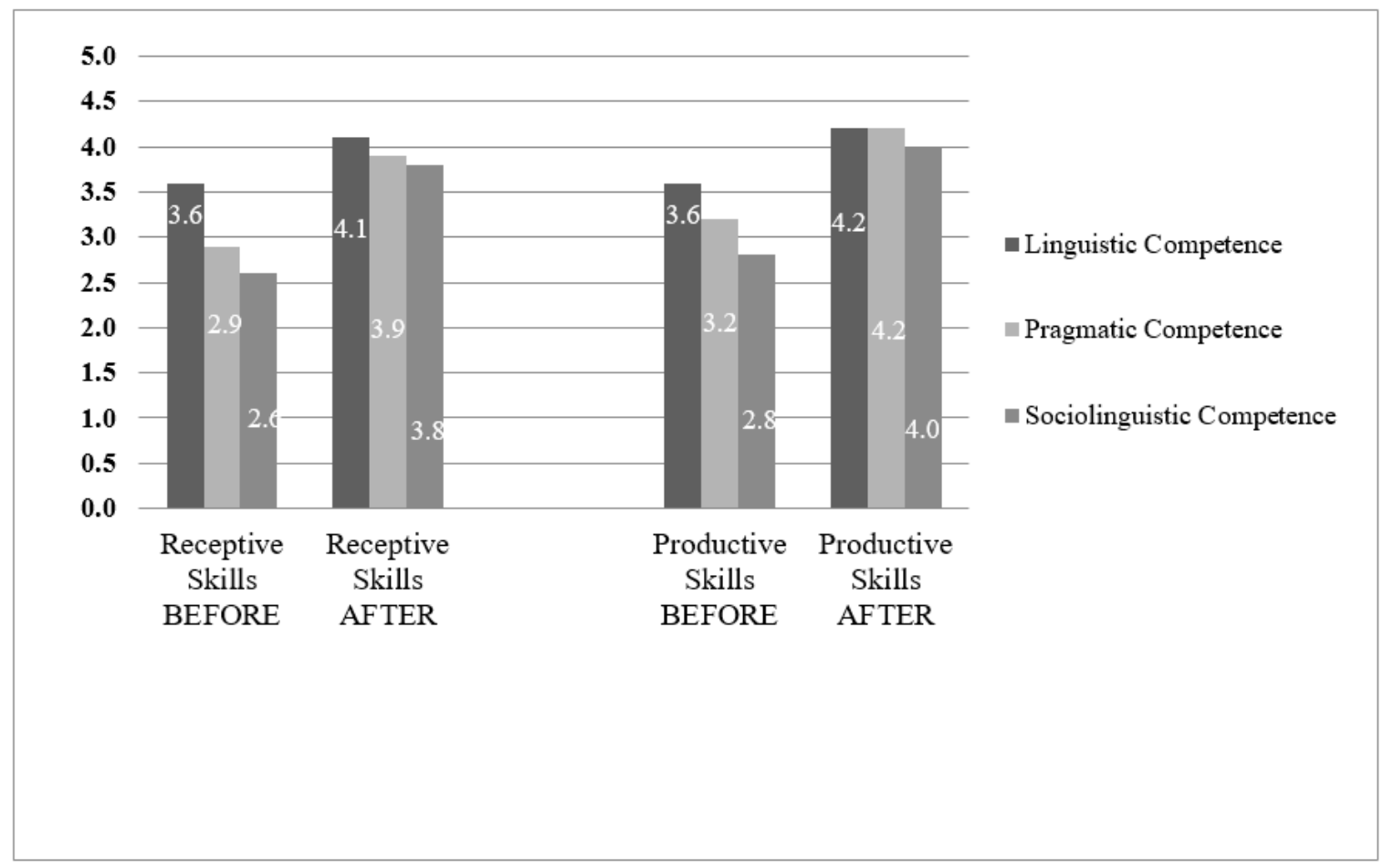

Figure 12. Emphasis (0-5) on Competences in Receptive and Productive Skills before vs. after Professional Learning.

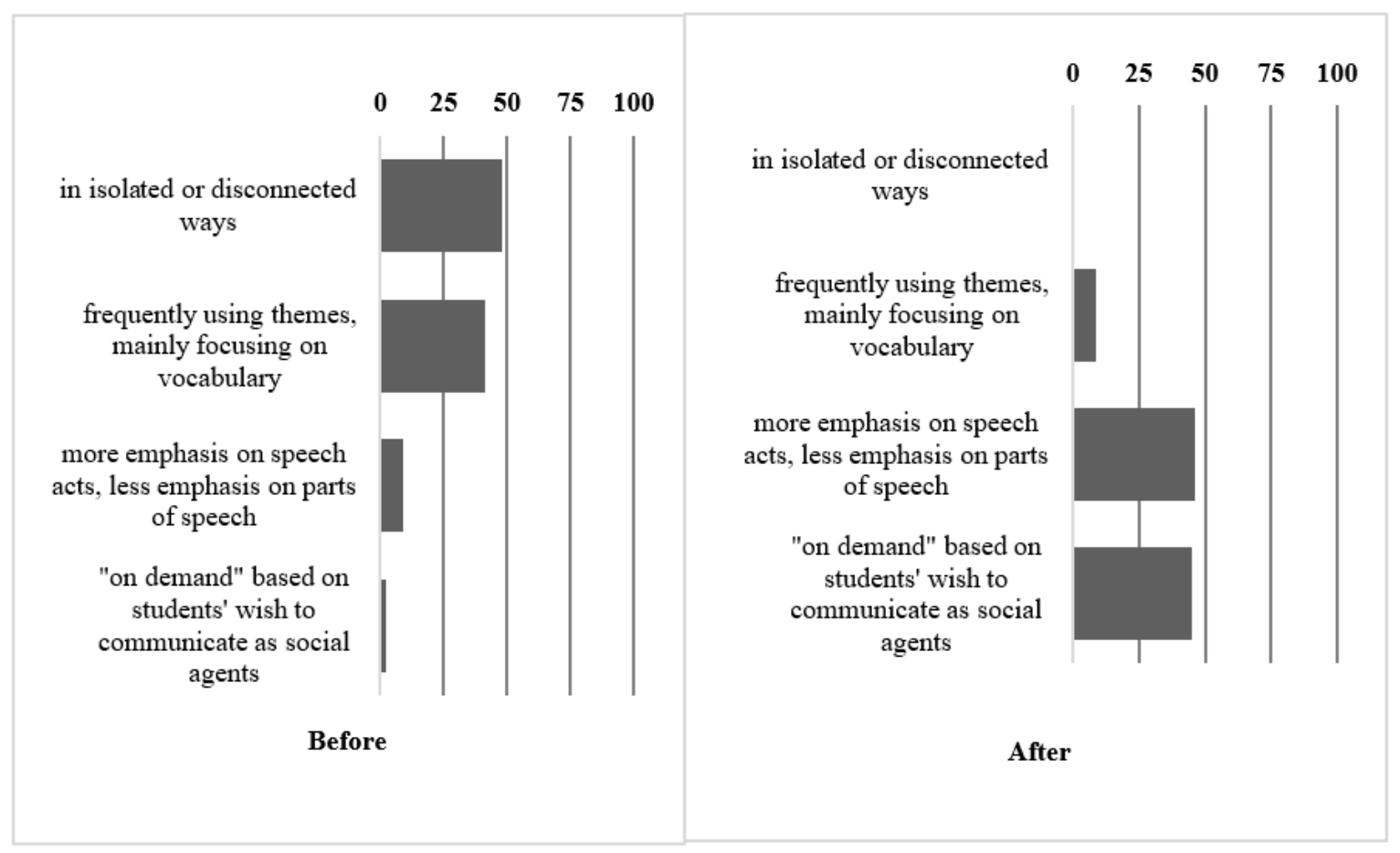

Figure 13. Presentation of Language (\%) before vs. after Professional Learning.

Lastly, when considering assessment/evaluation, where the teachers had initially reported focusing their feedback on grammatical accuracy and orthographic control above all before their CEFR-related experiences, after their professional learning, the teachers reported now prioritizing functional competence, alongside pragmatic and sociolinguistic appropriateness, fluency, coherence and cohesion, and vocabulary range and control (see Figure 14). This is in line with Vandergrift's (2015) finding that familiarity with the DELF 
had expanded Canadian FSL teachers' focus from assessing the acquisition of isolated grammatical rules to assessing more contextualized language use. It is also in keeping with the principle of formative assessment at the heart of the action-oriented approach to taskbased language teaching that underlies the current CEFR-informed Ontario FSL guidelines. According to Piccardo (2014, p. 43), assessment in such an approach must be based on "what the social agent is able to do in a real situation." Finally, the teachers in the present paper reported a noticeable shift in the focus they allotted to each skill on summative evaluation. Before their professional learning, the teachers reported focusing $60 \%$ of their evaluation on reading and writing skills and only $40 \%$ on listening and speaking. However, after their CEFR related learning, the teachers reported now prioritizing oral skills (56\%) over written skills (44\%) in their assessment and evaluation practices.

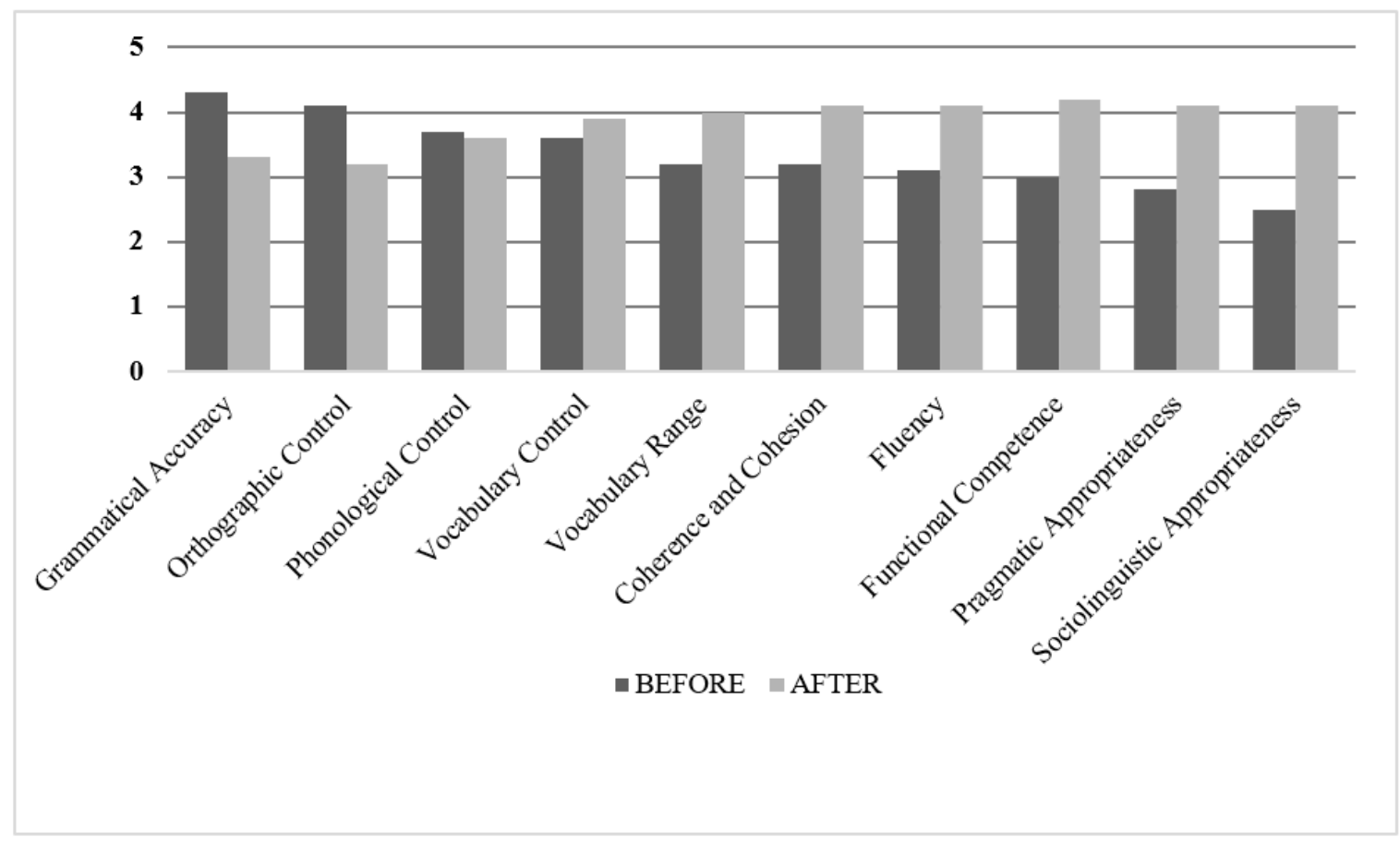

Figure 14. Frequency (0-5) of Targeting Aspects of Students' Work before vs. after Professional Learning.

\section{Conclusions}

In describing both the self-reported instructional practices of a group of early-CEFRadopter Ontario FSL teachers before versus after engaging in intensive and extensive CEFRrelated professional learning and the areas of strength and opportunities for proficiency improvement in the DELF exam results for a group of highly-motivated Ontario FSL learners as they prepared to graduate from their programs, the present exploratory study opens a window onto how the CEFR is impacting the local landscape of FSL education in the province.

The teachers in the present study reported important shifts in their instructional practices as a result of their CEFR-related learning that are in keeping with the current CEFR-informed Ontario FSL curriculum and its action-oriented approach to task-based language teaching. These shifts in the teachers' reported planning, classroom delivery, and assessment/evaluation practices after their CEFR-related professional learning signal a clear movement away from the grammar-based model inspired by the previous FSL curriculum documents, where language learning and production were directed by themes and where teachers reported presenting language in isolation. Instead, the teachers are now reporting a more open model promoting language learning through genuine communication in authentic, everyday situations. The current FSL documents are heavily informed by the CEFR and thus promote an action-oriented approach in which language learning takes 
place in contexts which are meaningful to the students. In this actional approach, both what is learned (grammatical content and vocabulary) and how students demonstrate language competence (through the successful accomplishment of carefully crafted pedagogical tasks) are determined based on the needs of the students to communicate in real-life situations.

Such changes in the teachers' reported instructional practices seem well poised to scaffold students as they grapple with the types of FSL proficiency challenges identified in the present study through the DELF exam results for students who had studied primarily under the previous FSL guidelines, which privileged a focus on form over function. While the DELF exam results revealed the students' strengths in reading, in following instructions and describing and presenting information in writing, and in phonological accuracy and the ability to respond and/or share precise ideas when speaking, they also revealed significant challenges with respect to morphosyntactic accuracy and vocabulary range and accuracy in both the written and oral production components. These challenges highlight the difficulty the students experienced deploying their grammatical and lexical knowledge gained through a focus on form under the previous FSL guidelines to serve the type of communication required in the interactive tasks of the CEFR-informed DELF exam-the same types of tasks at the heart of the current CEFR-informed Ontario FSL curriculum with its action-oriented approach to task-based language teaching. These difficulties echo VanPatten's (2016, p. 656) caution against the simplistic assumption that "explicit rule + practice $=$ proficiency" and underscore the opportunity for the CEFR to positively impact students' FSL learning in the province.

While the changes documented in the teachers' reported instructional practices after engaging in intensive and extensive CEFR-informed professional learning auger well for addressing these challenges and enhancing student proficiency, it must be borne in mind that these teachers were selected by their boards for participation in the study and may therefore be among the most positively-oriented and progressive early adopters of the CEFR in the province and that relying on their self-reports and retrospective reflections does not necessarily capture the full reality of their instructional practices. Examining observational classroom data from a broader swath of the province's FSL teachers would be a crucial next step, as would be examining additional measures of student proficiency in non-test settings, according to program type, among less-motivated learners, and, in time, with students who have completed their studies under the province's current CEFRinformed FSL guidelines. Despite these methodological limitations, this exploratory study suggests important pathways for continued research on the acquisition of French as a second language and opens a useful window for scholars and educational stakeholders onto how the CEFR is impacting FSL education at the local level in Ontario.

Author Contributions: Conceptualization, K.R.; Formal analysis, K.R.; Funding acquisition, K.R.; Investigation, K.R.; Methodology, K.R.; Project administration, K.R.; Supervision, K.R.; Writingoriginal draft, A.P.; Writing-review \& editing, K.R. and I.L. All authors have read and agreed to the published version of the manuscript.

Funding: This research draws on two projects funded by the Government of Ontario and the Government of Canada through the Department of Canadian Heritage.

Institutional Review Board Statement: The protocols were approved through Curriculum Services Canada (CSC 611-LGY 769).

Informed Consent Statement: All participating teachers provided their informed consent for inclusion before participating in the study. Informed consent was also obtained from all participating students and their parents before the study began.

Data Availability Statement: Restrictions apply to the availability of these data. Data were obtained through Curriculum Services Canada and are available from the authors with the permission of Curriculum Services Canada.

Conflicts of Interest: The authors declare no conflict of interest. 


\section{References}

Arnott, Stephanie. 2013. Canadian Empirical Research on the CEFR: Laying the Groundwork for Future Research. Annotated Bibliography for the Canadian Association of Second Language Teachers/l'Association Canadienne des Professeurs de langues Secondes. Available online: https:/ / www.caslt.org/files/pd/resources/research/2013-panorama-empiricalresearch-cefr-en.pdf (accessed on 6 May 2020).

Arnott, Stephanie, Lace Marie Brogden, Farahnaz Faez, Murielle Péguret, Enrica Piccardo, Katherine Rehner, Shelley K. Taylor, and Meike Wernicke. 2017. The common European framework of reference (CEFR) in Canada: A research agenda. Canadian Journal of Applied Linguistics 20: 31-54.

Bourguignon, Claire. 2010. Pour Enseigner les Langues Avec le CECRL: Clés et Conseils. Paris: Delgrave.

Centre International d'Etudes Pédagogiques CIEP. 2021. Detailed Information on DELF Examinations. Available online: https: / / www.france-education-international.fr/en/delf-tout-public/detailed-information-the-examinations (accessed on 1 January 2021).

Council of Atlantic Ministers of Education and Training. 2010. Literacy: Key to Learning and Path to Prosperity-An Action Plan for Atlantic Canada 2009-2014. Available online: https://immediac.blob.core.windows.net/cametcamef/images/eng/docs/2010\%2 0Literacy\%20Progress\%20Report\%20ENGLISH\%20FINAL.pdf (accessed on 6 May 2020).

Council of Europe. 2001. Common European Framework of Reference for Languages: Learning, Teaching, Assessment; Cambridge: Cambridge University Press. Available online: https:/ / rm.coe.int/1680459f97 (accessed on 6 May 2020).

De Veaux, Richard D., Paul F. Velleman, and David E. Bock. 2011. Stats: Data and Models, 3rd ed. Boston: Pearson/Addison Wesley.

DestinatiONtario DELF. 2021. Parent and Student Portal for Ontario Students Preparing for the DELF. Available online: https: / / destinationdelf.ca/ (accessed on 13 January 2021).

Ellis, Rod. 2003. Task-Based Language Teaching and Learning. Oxford: Oxford University Press.

Ellis, Rod, Peter Skehan, Shaofeng Li, Natsuko Shintani, and Craig Lambert. 2019. Task-Based Language Teaching: Theory and Practice. Cambridge: Cambridge University Press. [CrossRef]

Faez, Farahnaz, Shelley Taylor, Suzanne Majhanovich, Patrick Brown, and Maureen Smith. 2011a. Teacher reactions to CEFR's task-based approach for FSL classrooms. Synergies Europe 6: 109-20.

Faez, Farahnaz, Suzanne Majhanovich, Shelley K. Taylor, Maureen Smith, and Kelly Crowley. 2011b. The power of "Can Do" statements: Teachers' perceptions of CEFR-informed instruction in French as a second language classrooms in Ontario. Canadian Journal of Applied Linguistics 14: 1-19.

Halliday, Michael Alexander Kirkwood. 1985. An Introduction to Functional Grammar. London: Arnold.

Kristmanson, Paula, Chantal Lafargue, and Karla Culligan. 2013. Experiences with autonomy: Learners' voices on language learning. The Canadian Modern Language Review 69: 462-86. [CrossRef]

Little, David. 2006. The Common European Framework of Reference for Languages: Contents, purpose, origin, reception and impact. Language Teaching 39: 167-90. [CrossRef]

Long, Michael H. 1985. A role for instruction in second language acquisition. In Modelling and Assessing Second Language Acquisition. Edited by Kenneth Hyltenstam and Manfred Pienemann. Clevedon: Multilingual Matters.

Long, Michael H. 2014. Second Language Acquisition and Task-Based Language Teaching. Hoboken: John Wiley \& Sons.

Lyster, Roy, and Leila Ranta. 1997. Corrective feedback and learner uptake: Negotiation of form in communicative classrooms. Studies in Second Language Acquisition 20: 37-66. [CrossRef]

Majhanovich, Suzanne, Farahnaz Faez, Maureen Smith, Shelley Taylor, and Larry Vandergrift. 2010. Describing FSL Language Competencies: The CEFR within an Ontario Context. Unpublished manuscript. London: Western University.

Mison, Sara, and In Chull Jang. 2011. Canadian FSL teachers' assessment practices and needs: Implications for the adoption of the CEFR in a Canadian context. Synergies Europe 6: 99-108.

Moonen, Machteld, Evelien Stoutjesdijk, Rick de Graaff, and Alessandra Corda. 2013. Implementing CEFR in secondary education: Impact on FL teachers' educational and assessment practice. International Journal of Applied Linguistics 23: 226-46. [CrossRef]

Mui, Tiffany. 2015. Professional Development Based on the New CEFR and the New Ontario French Immersion Curriculum: A Case Study of Reflective Practice. Master's dissertation, Western University, London, ON, Canada. Unpublished work. Available online: https:/ / ir.lib.uwo.ca/etd/2827 (accessed on 6 May 2020).

Nunan, David. 2004. Task-Based Language Teaching. Cambridge: Cambridge University Press. [CrossRef]

Ontario Ministry of Education. 1980. French Core Programs, 1980: Curriculum Guidelines for the Primary, Junior, Intermediate and Senior Divisions. Toronto: Ontario Ministry of Education. [CrossRef]

Ontario Ministry of Education. 1998. The Ontario Curriculum, French as a Second Language: Core French, Grades 4-8. Toronto: Ontario Ministry of Education.

Ontario Ministry of Education. 1999. The Ontario Curriculum, Grades 9 and 10: French As a Second Language-Core, Extended, and Immersion French. Toronto: Ontario Ministry of Education.

Ontario Ministry of Education. 2000. The Ontario Curriculum, French as a Second Language-Core, Extended, and Immersion French, Grades 11 and 12. Toronto: Ontario Ministry of Education.

Ontario Ministry of Education. 2001. The Ontario Curriculum, French as a Second Language: Extended French, Grades 4-8; French Immersion, Grades 1-8. Toronto: Ontario Ministry of Education. 
Ontario Ministry of Education. 2013. The Ontario Curriculum, French as a Second Language: Core French Grades 4-8, Extended French Grades 4-8, French Immersion Grades 1-8. Toronto: Ontario Ministry of Education, Available online: www.ontario.ca/education (accessed on 6 May 2020).

Ontario Ministry of Education. 2014. The Ontario Curriculum, Grades 9-12: French as a Second Language-Core, Extended and Immersion. Toronto: Ontario Ministry of Education, Available online: www.ontario.ca/education (accessed on 6 May 2020).

Piccardo, Enrica. 2013. (Re)conceptualiser l'enseignement d'une langue seconde à l'aide d'outils d'évaluations: Comment les enseignants canadiens perçoivent le CECR. Canadian Modern Language Review 69: 386-414. [CrossRef]

Piccardo, Enrica. 2014. From Communicative to Action-Oriented: A Research Pathway. Toronto: Curriculum Services Canada.

Piccardo, Enrica, Brian North, and Eleonora Maldina. 2019. Innovation and reform in course planning, teaching, and assessment: The CEFR in Canada and Switzerland, a comparative study. Canadian Journal of Applied Linguistics 22: 103-28. [CrossRef]

Rehner, Katherine. 2014. French as a Second Language (FSL) Student Proficiency and Confidence Pilot Project Report 2013-2014: A Report of Findings. Toronto: Ontario Ministry of Education and Curriculum Services Canada, Available online: https://transformingfsl.ca/ wp-content/uploads/2015/12/Student_Proficiency_Full_Report.pdf (accessed on 6 May 2020).

Rehner, Katherine. 2017. The CEFR in Ontario: Transforming Classroom Practice. Research Report.. Toronto: Ontario Ministry of Education and Curriculum Services Canada, Available online: https:/ / transformingfsl.ca/en/resources/the-cefr-in-ontario-transformingclassroom-practice/ (accessed on 6 May 2020).

Richards, Jack C. 2013. Curriculum approaches in language teaching: Forward, central, and backward design. Relc Journal 44: 5-33. [CrossRef]

Richards, Jack C., and Theodore S. Rodgers. 2014. Approaches and Methods in Language Teaching. Cambridge: Cambridge University Press.

Saskatchewan Ministry of Education. 2013. A Guide to Using the Common Framework of Reference (CEFR) with Learners of English as an Additional Language. Available online: http:/ / publications.gov.sk.ca/documents/11/82934-A\%20Guide\%20to\%20Using\% 20the\%20CFR\%20with\%20EAL\%20Learners.pdf (accessed on 6 May 2020).

Vandergrift, Larry. 2012. The DELF in Canada: Stakeholder Perceptions. The DELF in Canada: Stakeholder Perceptions. Ottawa: Canadian Association of Immersion Teachers, Available online: https://www.yumpu.com/s/BjCjN7Sc9ycT4yAD (accessed on 6 May 2020).

Vandergrift, Larry. 2015. The DELF in Canada: Perceptions of students, teachers, and parents. Canadian Modern Language Review 71: 52-74. [CrossRef]

VanPatten, Bill. 2016. Why explicit knowledge cannot become implicit knowledge. Foreign Language Annals 49: 650-57. [CrossRef] 